Article

\title{
Synthesis and Application of Heterogeneous Catalysts Based on Heteropolyacids for 5-Hydroxymethylfurfural Production from Glucose
}

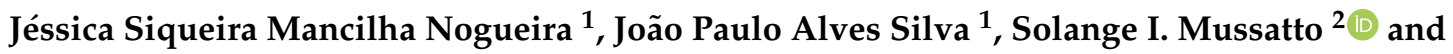 \\ Livia Melo Carneiro ${ }^{1, *}$ \\ 1 Department of Chemical Engineering, Engineering School of Lorena, University of São Paulo, \\ 12602-810 Lorena/SP, Brazil; jessicasmn@usp.br (J.S.M.N.); jpalves80@usp.br (J.P.A.S.) \\ 2 Novo Nordisk Foundation Center for Biosustainability, Technical University of Denmark, \\ 2800 Kongens Lyngby, Denmark; smussatto@biosustain.dtu.dk \\ * Correspondence: liviacarneiro@usp.br; Tel.: +55-12-31595162
}

Received: 22 December 2019; Accepted: 26 January 2020; Published: 4 February 2020 updates

\begin{abstract}
This study aimed to evaluate the synthesis and application of heterogeneous catalysts based on heteropolyacids for 5-hydroxymethylfurfural (HMF) production from glucose. Initially, assays were carried out in order to establish the most favorable catalyst synthesis conditions. For such purpose, calcination temperature $\left(300\right.$ or $\left.500{ }^{\circ} \mathrm{C}\right)$, type of support $\left(\mathrm{Nb}_{2} \mathrm{O}_{5}\right.$ or $\left.\mathrm{Al}_{2} \mathrm{O}_{3}\right)$, and active phase $\left(\mathrm{H}_{3} \mathrm{PW}_{12} \mathrm{O}_{40}-\mathrm{HPW}\right.$ or $\left.\mathrm{H}_{3} \mathrm{PMo}_{12} \mathrm{O}_{40}-\mathrm{HPMo}\right)$ were tested and combined based on Taguchi's $\mathrm{L}_{8}$ orthogonal array. As a result, $\mathrm{HPW}-\mathrm{Nb}_{2} \mathrm{O}_{5}$ calcined at $300^{\circ} \mathrm{C}$ was selected as it presented optimal HMF production performance ( $9.5 \%$ yield). Subsequently, the reaction conditions capable of maximizing HMF production from glucose using the selected catalyst were established. In these experiments, different temperatures $\left(160\right.$ or $\left.200{ }^{\circ} \mathrm{C}\right)$, acetone-to-water ratios $(1: 1$ or 3:1 v/v), glucose concentrations ( 50 or $100 \mathrm{~g} / \mathrm{L}$ ), and catalyst concentrations ( 1 or $5 \%$ w/v) were evaluated according to a Taguchi's $\mathrm{L}_{16}$ experimental design. The conditions that resulted in the highest HMF yield $(40.8 \%)$ consisted of using $50 \mathrm{~g} / \mathrm{L}$ of glucose at $160^{\circ} \mathrm{C}, 1: 1(\mathrm{v} / \mathrm{v})$ acetone-to-water ratio, and catalyst concentration of $5 \%(w / v)$. Recycling tests revealed that the catalyst can be used in four runs, which results in the same HMF yield (approx. 40\%).
\end{abstract}

Keywords: 5-hydroxymethylfurfural; glucose; heteropolyacid catalysts

\section{Introduction}

In an attempt to reduce global dependence on fossil resources, which are associated with important negative environmental impacts, new technologies have been developed that aim to use renewable feedstock (lignocellulosic raw materials) for the production of fuels and chemicals [1]. Lignocellulosic biomass is an interesting raw material for such application, since it is widely available in the form of agricultural, agro-industrial, and forest residues, inexpensive, and rich in sugars that can be used for producing numerous compounds of industrial interest. Among the compounds that can be produced from lignocellulosic materials, furans such as furfural and 5-hydroxymethylfurfural (HMF) are molecules of enormous interest, since they have numerous applications in the chemical industry [2].

HMF is a building block platform chemical that can be used to produce various other compounds, including 2,5-dimethylfuran (DMF) and liquid fuels, as well as high added-value products such as polyesters, dialdehydes, ethers, among others [3,4]. Due to its wide-ranging applications, it has been considered as one of the 10 highest value platform molecules by the United States Department of Energy $[5,6]$. Recently, there has been enormous interest in new processes aiming to obtain HMF in 
order to supply the booming market and provide more sustainable production alternatives. Leading companies in renewable technologies, e.g., Avantium and AVA Biochem, have sought processes in order to produce HMF from lignocellulosic biomass in a pilot scale aiming at the production of bioplastics and other compounds [4,7]. Production of 2,5-furan-dicarboxylic acid (FDCA) is particularly highlighted due to its application as precursor monomer of the bioplastic polyethylene furanoate (PEF), which is a potential replacement for the conventional polymer polyethylene terephthalate (PET) $[5,6]$.

HMF can be obtained by dehydrating hexose sugars, such as glucose or fructose. However, glucose costs less when compared to fructose and can be found in greater amounts in the form of cellulose in lignocellulosic materials, therefore being more attractive to be used in large-scale HMF production. The process to convert glucose into HMF is influenced by several variables, such as the temperature, type of catalyst, reaction time, and reaction medium composition. Regarding the reaction medium, a variety of solvents has been evaluated for such a purpose, including aqueous, organic, and biphasic systems (water mixtures and organic solvents), as well as ionic liquids [8-11]. Glucose dehydration reactions tend to be more selective in the presence of aprotic solvents, e.g., dimethylsulfoxide (DMSO), tetrahydrofuran, acetone, and n-butanol. Aqueous media have resulted in low yields, i.e., close to $20 \%[7,12]$, as they favor the formation of undesirable products (humin and furfural) and HMF rehydration reactions, which lead to the production of levulinic and formic acids $[5,13]$. Ionic liquids have provided conversion yields of over 30\% [14,15]; however, final product separation is more difficult when using these solvents, in addition to being quite costly and toxic [3]. Taking all these considerations into account, biphasic systems (water/solvent) have been considered the most interesting alternative to HMF production.

The catalyst is also a significant variable that affects glucose conversion into HMF. When compared to homogeneous catalysts, the use of heterogeneous catalysts has shown better selectivity and lower costs, especially because they ease product separation, as well as catalyst recovery and reuse $[7,16]$. Several heterogeneous acid catalysts such as zeolites, metal oxides, silica, aluminosilicates, alumina, sulfated and tungsten zirconia, and superacid catalysts, have been studied for such a process. However, catalysts based on heteropolyacids have been slightly explored for HMF production, although these catalysts have shown promising results in reactions such as esterification [17], transesterification [18], hydrodesulfurization [19], glycerol dehydration [20], benzaldehyde acetylation [21], and isomerization [22]. Some studies showed HMF yields over 30\% using $\mathrm{H}_{3} \mathrm{PW}_{12} \mathrm{O}_{40}-\mathrm{HPW}$ as homogeneous catalyst combined with boric acid in liquid ionic media [23] or using HPW as heterogeneous catalyst by the reaction with a liquid ionic [24] or $\mathrm{AgNO}_{3}$ [25] in a biphasic system.

Thus, this study aimed to define the conditions to prepare heterogeneous catalysts based on heteropolyacids to be used in HMF production from glucose. Initially, assays were carried out to establish the conditions for catalyst synthesis. Different conditions were tested, such as calcination temperature $\left(300\right.$ or $\left.500{ }^{\circ} \mathrm{C}\right)$, type of support $\left(\mathrm{Nb}_{2} \mathrm{O}_{5}\right.$ or $\left.\mathrm{Al}_{2} \mathrm{O}_{3}\right)$, and active phase $\left(\mathrm{H}_{3} \mathrm{PW}_{12} \mathrm{O}_{40}-\mathrm{HPW}\right.$ or $\mathrm{H}_{3} \mathrm{PMo}_{12} \mathrm{O}_{40}-\mathrm{HPMo}$ ). The catalyst that presented optimal performance to convert glucose into HMF was selected, and then the reaction conditions capable of maximizing HMF production using it were established. Finally, the possibility of catalyst recycling was also investigated.

\section{Materials and Methods}

\subsection{Catalyst Preparation}

Heteropolyacid catalysts were synthesized in duplicate according to Taguchi's $\mathrm{L}_{8}$ orthogonal array presented in Table 1, through which different calcination temperatures ( 300 or $500{ }^{\circ} \mathrm{C}$ ), $30 \%$ $(w / w)$ active phases $\left(\mathrm{H}_{3} \mathrm{PW}_{12} \mathrm{O}_{40}-\mathrm{HPW}\right.$ or $\left.\mathrm{H}_{3} \mathrm{PMo}_{12} \mathrm{O}_{40}-\mathrm{HPMo}\right)$, and supports $\left(\mathrm{Nb}_{2} \mathrm{O}_{5}\right.$ or $\left.\mathrm{Al}_{2} \mathrm{O}_{3}\right)$ were combined, resulting in 16 different catalysts. The choice of the supports and active phases were made so that their combination resulted in catalysts with Lewis and Brønsted acid sites, which was 
derived from the support and active phase, respectively. The supports $\mathrm{Nb}_{2} \mathrm{O}_{5}$ (HY-340) and $\mathrm{Al}_{2} \mathrm{O}_{3}$ were supplied by Companhia Brasileira de Metalurgia e Mineração (CBMM) and Alcoa, respectively.

The catalysts were prepared according to the incipient wetness impregnation method which uses an amount of solvent which is lower than or equal to that required to fill in the support pores. For such a purpose, the active phase (HPW or HPMo) was dissolved in $70 \%$ ethanol solution at ambient temperature and mixed with the support $\left(\mathrm{Nb}_{2} \mathrm{O}_{5}\right.$ or $\left.\mathrm{Al}_{2} \mathrm{O}_{3}\right)$ in three successive steps until reaching a final metal concentration of $30 \%$. The catalytic solid was then dried at $100{ }^{\circ} \mathrm{C}$ for $2 \mathrm{~h}$ and subsequently calcined at 300 or $500{ }^{\circ} \mathrm{C}$ for $3 \mathrm{~h}$, according to the conditions shown in Table 1 . The assays were carried out in duplicate.

\subsection{HMF Production}

The catalytic performance of different heteropolyacid catalysts prepared according to the experimental design given in Table 1 was evaluated regarding catalytic performance in order to convert glucose into HMF. The catalytic reactions carried out using $100 \mathrm{~mL}$ of reaction medium at $160{ }^{\circ} \mathrm{C}$ using $1 \% w / v$ of catalyst, $100 \mathrm{~g} / \mathrm{L}$ of glucose, $1: 1 w / w$ acetone-to-water ratio, and $300 \mathrm{rpm}$ over $30 \mathrm{~min}$. The catalyst that achieved optimal HMF production performance was then used in subsequent experiments with the aim of optimizing reaction conditions.

For optimization experiments, different reaction conditions, such as temperature $\left(160\right.$ or $\left.200{ }^{\circ} \mathrm{C}\right)$, acetone-to-water ratio $(1: 1$ or $3: 1 \mathrm{v} / \mathrm{v})$, glucose concentration $(50$ or $100 \mathrm{~g} / \mathrm{L})$, and catalyst concentration $\left(1 \%\right.$ or $5 \%$ w/v) were used based on Taguchi's $\mathrm{L}_{16}$ experimental design. The column " $\mathrm{E}$ " had no factor associated to estimate the experimental design error. All catalytic tests were performed in pressurized stainless steel reactors (Parr series 4566). At the end of the runs, the catalyst was recovered from the reaction mixture by centrifugation at $2000 \times g$ for $20 \mathrm{~min}$ and calcined at $300{ }^{\circ} \mathrm{C}$ for $3 \mathrm{~h}$.

Catalyst stability was evaluated by reusing it in successive batch runs performed under optimized process conditions.

\subsection{Analytical Methods}

The crystalline structure of the catalyst, support, and active phase was evaluated by X-Ray Powder Diffraction (XRD) using a PANalytical Model Empyrean X-ray diffractometer with $\mathrm{CuK} \alpha 2 \theta$ radiation $(\lambda=1.5418 \AA)$ at $40 \mathrm{kV}$ and $30 \mathrm{~mA}$, angle ranging between $10^{\circ}$ and $90^{\circ}$, at step size of $0.02^{\circ}$ and countdown time of $50 \mathrm{~s}$ per run. The catalyst surface morphology and structure were analyzed by SEM/EDX using Hitachi TM 3000 and Swifted 3000 equipment.

The textural properties of catalysts were investigated by specific surface area analysis using Quantachrome NOVA 2200e. For performing the analysis, a sample of $0.2 \mathrm{~g}$ was added to a glass cell and heated at $200{ }^{\circ} \mathrm{C}$ for $2 \mathrm{~h}$ under vacuum in order to remove impurities adsorbed on the catalyst surface. Specific surface area and pore volume were calculated by the Brunauer-Emmett-Teller (BET) the Barrett-Joyner-Halenda (BJH) methods, respectively.

The catalyst surface acidity was determined by acid-base titrations. In this analysis, $0.1 \mathrm{~g}$ of catalyst was suspended in $20 \mathrm{~mL}$ of $0.1 \mathrm{M} \mathrm{NaOH}$. The suspension was stirred for $3 \mathrm{~h}$ at room temperature and then titrated with $0.1 \mathrm{M} \mathrm{HCl}$ in the presence of phenolphthalein. The catalyst surface acidity was expressed in $\mathrm{mmol} \mathrm{H}^{+} / \mathrm{g}$ catalyst. The active phase thermal stability was evaluated by thermogravimetry (TGA) and derivative thermogravimetry (DTG) analysis using a Shimadzu TGA 50 equipment with $50 \mathrm{~mL} / \mathrm{min}$ of nitrogen flow, heating rate of $10^{\circ} \mathrm{C} / \mathrm{min}$ in a temperature range of 30 to $1000^{\circ} \mathrm{C}$.

Glucose concentration was determined by high performance liquid chromatography (HPLC) using an Agilent Technologies 1260 Infinity chromatograph equipped with an isocratic pump, a refractive index detector and a Bio-Rad Aminex HPX-87H column $(300 \times 7.8 \mathrm{~mm})$. Operational conditions were temperature of $45^{\circ} \mathrm{C}, 0.005 \mathrm{~mol} / \mathrm{L}$ using sulfuric acid as eluent at a flow rate of $0.6 \mathrm{~mL} / \mathrm{min}$ and sample volume of $0.02 \mathrm{~mL}$. HMF concentration was also determined by HPLC, but using a UV detector (at $276 \mathrm{~nm})$, a Waters Spherisorb C18 $5 \mu \mathrm{m}$ column $(100 \times 4.6 \mathrm{~mm})$ at room temperature, 
1:8 $\mathrm{v} / \mathrm{v}$ acetonitrile-to-water ratio using $1 \%$ of acetic acid as eluent, flow rate of $0.8 \mathrm{~mL} / \mathrm{min}$, and sample volume of $0.02 \mathrm{~mL}$. Glucose conversion $\left(\mathrm{X}_{\mathrm{Glu}}\right)$ and $\mathrm{HMF}$ yield $\left(\mathrm{Y}_{\mathrm{HMF}}\right)$ were calculated according to Equations (1) and (2).

$$
\begin{gathered}
X_{\text {Glu }}(\%)=\frac{[\text { Glucose }]_{\text {initial }}-[\text { Glucose }]_{\text {final }}}{[\text { Glucose }]_{\text {initial }}} \cdot 100, \\
Y_{H M F}(\%)=\frac{[\text { HMF }]_{\text {produced }}}{[\text { Glucose }]_{\text {initial }}} \cdot 100 .
\end{gathered}
$$

\section{Results and Discussion}

\subsection{Catalyst Synthesis}

Table 1 summarizes the conditions used to prepare the catalysts as well as their performance to convert glucose into $\mathrm{HMF}$ in terms of $\mathrm{HMF}$ yield $\left(\mathrm{Y}_{\mathrm{HMF}}\right)$ and glucose conversion $\left(\mathrm{X}_{\mathrm{Glu}}\right)$. As it can be seen, $\mathrm{HMF}$ yield ranged from $0.7 \%$ to $9.5 \%$ and glucose conversion from $65.3 \%$ to $93.6 \%$ according to the conditions established to prepare the catalyst. These results show that preparation conditions had an important influence on the effectiveness of glucose conversion into HMF. In some cases, the produced catalyst allowed achieving high glucose conversion rates, i.e., about 90\% (assays 1, 3, 5, and 7). However, the highest HMF yield, about 9.5\%, was achieved in assay 2, in which glucose conversion was only 75\%. A high glucose conversion without a proportional HMF yield, as observed in other cases, suggests the formation of reaction by-products. In fact, the formation of humin, levulinic acid, furfural, and formic acid, which have been reported in literature as by-products of a glucose dehydration reaction to $\mathrm{HMF}$, is often associated with reaction conditions, mainly to the use of solvents and high temperatures $[5,26]$.

Table 1. Taguchi's $\mathrm{L}_{8}$ orthogonal array to evaluate the effect of calcination temperature, support and active phase on heterogeneous catalysts preparation on 5-Hydroxymethylfurfural yield $\left(\mathrm{Y}_{\mathrm{HMF}}\right)$ and

\begin{tabular}{|c|c|c|c|c|c|c|c|c|c|}
\hline \multirow[b]{2}{*}{ Catalyst } & \multicolumn{7}{|c|}{ Experimental Conditions (Factors and Interactions) } & \multicolumn{2}{|c|}{ Response Variables } \\
\hline & $\begin{array}{l}\text { A Temp. } \\
\left({ }^{\circ} \mathrm{C}\right)\end{array}$ & $\begin{array}{c}\text { B } \\
\text { Support }\end{array}$ & AB & $\begin{array}{c}\text { C Active } \\
\text { phase }\end{array}$ & $\mathrm{AC}$ & BC & $\mathrm{ABC}$ & $\mathrm{Y}_{\mathrm{HMF}}{ }^{1}(\%)$ & $X_{\text {Glu }}{ }^{2}(\%)$ \\
\hline \multirow{2}{*}{1} & \multirow[b]{2}{*}{300} & \multirow[b]{2}{*}{$\mathrm{Nb}$} & \multirow{2}{*}{1} & \multirow{2}{*}{ HPMo } & \multirow{2}{*}{1} & \multirow{2}{*}{1} & \multirow[b]{2}{*}{1} & 3.0 & 92.3 \\
\hline & & & & & & & & 2.8 & 93.6 \\
\hline \multirow{2}{*}{2} & \multirow{2}{*}{300} & \multirow{2}{*}{$\mathrm{Nb}$} & \multirow{2}{*}{1} & \multirow{2}{*}{$\mathrm{HPW}$} & \multirow{2}{*}{2} & \multirow{2}{*}{2} & \multirow[b]{2}{*}{2} & 9.5 & 75.0 \\
\hline & & & & & & & & 9.4 & 75.7 \\
\hline \multirow{2}{*}{3} & \multirow{2}{*}{300} & \multirow{2}{*}{$\mathrm{Al}$} & \multirow{2}{*}{2} & \multirow{2}{*}{ HPMo } & \multirow{2}{*}{1} & \multirow{2}{*}{2} & \multirow{2}{*}{2} & 4.4 & 90.3 \\
\hline & & & & & & & & 3.7 & 85.3 \\
\hline \multirow{2}{*}{4} & \multirow{2}{*}{300} & \multirow{2}{*}{$\mathrm{Al}$} & \multirow{2}{*}{2} & \multirow{2}{*}{ HPW } & \multirow{2}{*}{2} & \multirow{2}{*}{1} & \multirow{2}{*}{1} & 0.8 & 69.8 \\
\hline & & & & & & & & 0.8 & 67.2 \\
\hline 5 & 500 & $\mathrm{Nb}$ & 2 & HPMo & 2 & 1 & 2 & 6.9 & 91.8 \\
\hline J & 300 & $1 \mathrm{NO}$ & 2 & ПНГИІО & 2 & 1 & 2 & 7.0 & 90.7 \\
\hline 6 & 500 & $\mathrm{Nb}$ & 2 & HPW & 1 & 2 & 1 & 0.7 & 65.3 \\
\hline & 300 & 100 & 2 & ПТ & 1 & 2 & 1 & 0.8 & 66.1 \\
\hline 7 & 500 & $\mathrm{Al}$ & 1 & HРMo & 2 & 2 & 1 & 7.3 & 91.0 \\
\hline & & Al & 1 & НРМО & 2 & 2 & 1 & 7.7 & 87.6 \\
\hline 8 & 500 & $\mathrm{Al}$ & 1 & HPW & 1 & 1 & 2 & 0.7 & 70.6 \\
\hline & & & & & & & 2 & 0.7 & 68.9 \\
\hline
\end{tabular}
glucose conversion rate $\left(\mathrm{X}_{\mathrm{Glu}}\right)$.

${ }^{1} \mathrm{Y}_{\mathrm{HMF}}:$ 5-Hydroxymethylfurfural yield (\%). ${ }^{2} \mathrm{X}_{\mathrm{Glu}}$ : Glucose conversion (\%). ${ }^{1,2}$ All results are in duplicate.

The statistical significance of main effects and their interactions on response variables was verified by the analysis of variance (ANOVA). As shown in Table 2, the variation percentages explained by HMF yield and glucose conversion achieved a high coefficient of determination $\left(\mathrm{R}^{2}=99.8 \%\right.$ and $98.6 \%$, respectively). These results reveal that the variations observed for response variables 
(HMF yield and glucose conversion) can be effectively explained by catalyst preparation conditions. With respect to HMF yield, calcination temperature, support, active phase, and interaction effects $(\mathrm{AB}, \mathrm{AC}, \mathrm{BC}$, and $\mathrm{ABC})$ were significant at confidence level of $95 \%$; moreover, glucose conversion, calcination temperature, support, active phase, and $\mathrm{AB}$ and $\mathrm{AC}$ interactions were also significant at $95 \%$ confidence level.

Table 2. Analysis of variance of the main effects and their interactions on 5-hydroxymethylfurfural (HMF) yield $\left(\mathrm{Y}_{\mathrm{HMF}}\right)$ and glucose conversion $\left(\mathrm{X}_{\mathrm{Glu}}\right)$ based on Taguchi's $\mathrm{L}_{8}$ orthogonal array.

\begin{tabular}{ccc}
\hline \multirow{2}{*}{ Source of Variation } & \multicolumn{2}{c}{ Response Variables } \\
\cline { 2 - 3 } & $p$-Value for $\mathbf{Y}_{\text {HMF }}$ & $p$-Value for $\mathbf{X}_{\mathrm{Glu}}$ \\
\hline (A) Temperature & $0.0155^{*}$ & $0.0413^{*}$ \\
(B) Support & $<0.0001^{*}$ & $0.0237^{*}$ \\
(D) Active phase & $<0.0001^{*}$ & $0.0001^{*}$ \\
$\mathrm{AB}$ & $<0.0001^{*}$ & $0.0041^{*}$ \\
$\mathrm{AD}$ & $<0.0001^{*}$ & $0.0472^{*}$ \\
$\mathrm{BD}$ & $<0.0001^{*}$ & 0.2526 \\
$\mathrm{ABD}$ & $<0.0001^{*}$ & 0.0626 \\
\hline $\mathrm{R}^{2}$ & 0.9978 & 0.9862 \\
\hline${ }^{*}$ Significant at $95 \%$ confidence level: $p$ test $<0.05$.
\end{tabular}

The interaction effects of support and temperature for different active phases on HMF yield and glucose conversion are shown in Figure 1. Note that the highest HMF yields (Figure 1b) were obtained from reactions in which the catalyst was prepared by using HPW active phase supported on $\mathrm{Nb}_{2} \mathrm{O}_{5}$ and calcined at $300^{\circ} \mathrm{C}$. For the HPMo active phase, the type of support ( $\mathrm{Al}$ or $\mathrm{Nb}$ ) had no influence on final HMF yield, on the other hand, for this active phase, the catalysts calcined at $500{ }^{\circ} \mathrm{C}$ achieved higher HMF $(7.0 \%)$ yields if compared to those calcined at $300{ }^{\circ} \mathrm{C}(3.5 \%)$. For the HPW active phase calcined at $500{ }^{\circ} \mathrm{C}$, the type of support ( $\mathrm{Al}$ or $\mathrm{Nb}$ ) exerted no influence on the final $\mathrm{HMF}$ concentration. However, as for catalyst preparation using the same active phase calcined at $300{ }^{\circ} \mathrm{C}$, the catalyst supported in $\mathrm{Nb}$ was more effective at HMF production and achieved yields of over $9 \%$. These results suggest that the catalyst produced using HPW as active phase can achieve greater HMF production; however, such a result can only be reached when using $\mathrm{Nb}_{2} \mathrm{O}_{5}$ as support at $300{ }^{\circ} \mathrm{C}$ of calcination temperature. The highest $\mathrm{HMF}$ yield reached with $\mathrm{Nb}_{2} \mathrm{O}_{5}$ is probably associated with the presence of Lewis and Brönsted acid sites in this support, while $\mathrm{Al}_{2} \mathrm{O}_{3}$ only has Lewis sites on the surface [27].

For glucose conversion (Figure $1 \mathrm{~b}$ ), the highest conversions (above $85 \%$ ) were obtained by using catalyst with HPMo as active phase, regardless of the type of support or calcination temperature conditions. Regarding the HPW active phase, the catalyst supported in $\mathrm{Nb}_{2} \mathrm{O}_{5}$ and calcined at $300{ }^{\circ} \mathrm{C}$ resulted in higher glucose conversion $(75 \%)$ than the one calcined at $500{ }^{\circ} \mathrm{C}(65 \%)$; while for the catalyst supported in $\mathrm{Al}_{2} \mathrm{O}_{3}$, calcination temperature had no influence on glucose conversion (70\%). Despite the high glucose conversion for catalysts prepared with HPMo active phase, HMF production was low, which suggests that reactions using catalyst with HPMo as active phase result in higher by-product formation and lower HMF selectivity. Thereby, the $\mathrm{HPW} / \mathrm{Nb}_{2} \mathrm{O}_{5}-300{ }^{\circ} \mathrm{C}$ catalyst was selected as the most desirable catalyst for converting glucose into HMF. 


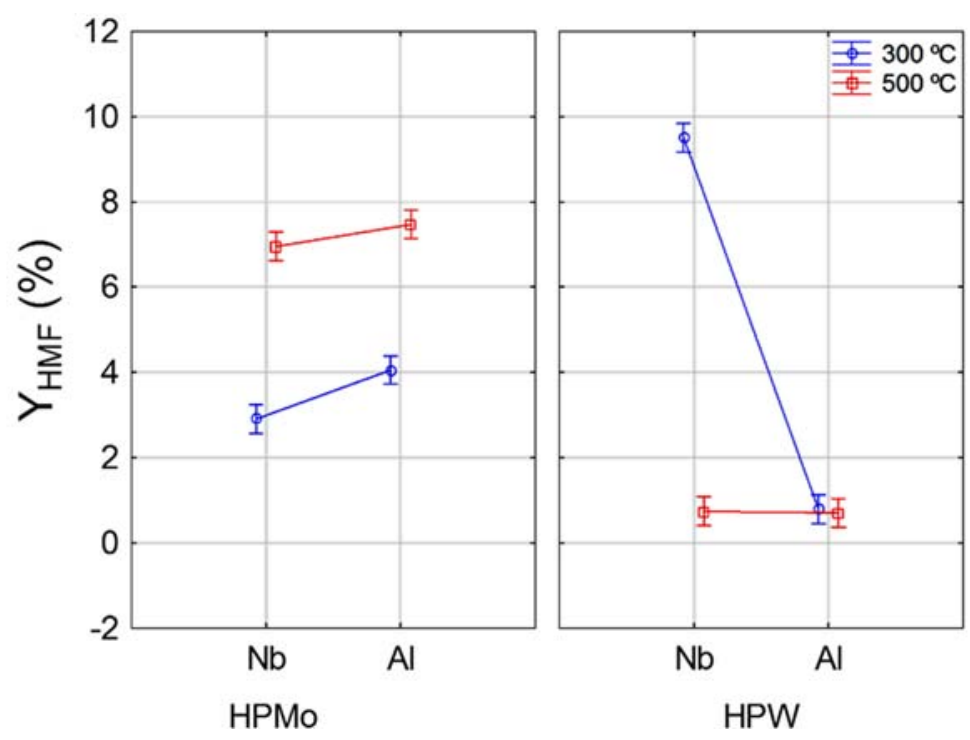

(a)

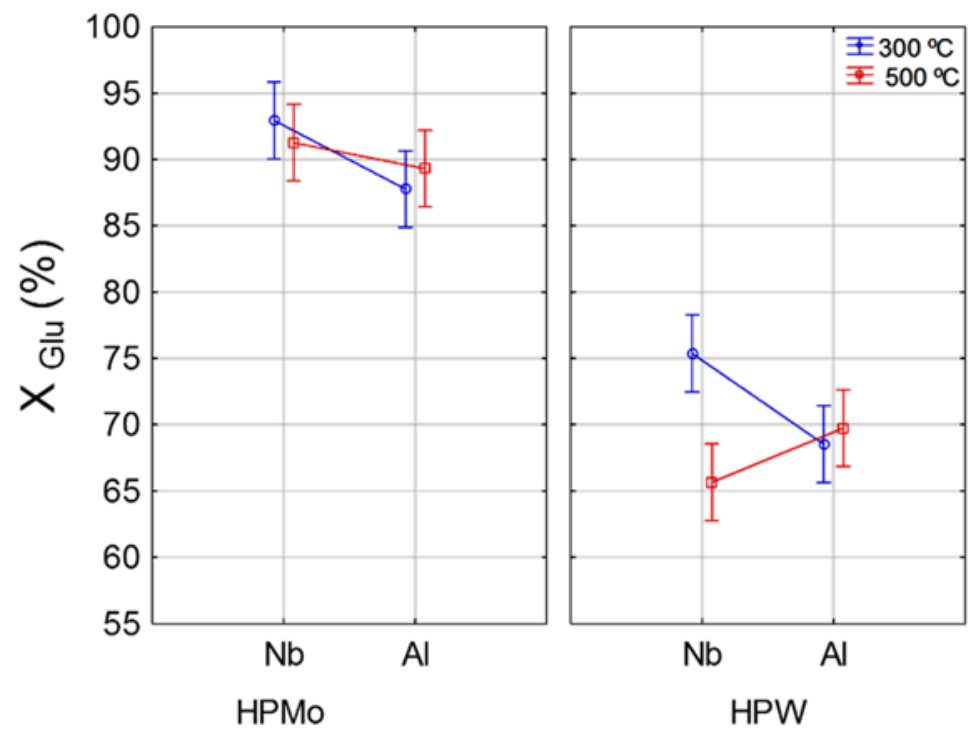

(b)

Figure 1. Interaction effect between temperature and support for different active phases (HPW and HPMo) on HMF yield ( $\left.\mathrm{Y}_{\mathrm{HMF}}\right)(\mathbf{a})$ and glucose conversion $\left(\mathrm{X}_{\mathrm{Glu}}\right)(\mathbf{b})$.

\subsection{Catalyst Characterization}

The active phase thermal stability of the selected catalyst was evaluated by thermogravimetric analysis (TGA) with the aim of determining whether the Keggin structure would remain at $300{ }^{\circ} \mathrm{C}$ or not, since it is the calcination temperature of the catalyst that achieved optimal performance. TGA profile shown in Figure 2 revealed that the main weight loss (approx. $7 \%$ ) occurred until $208^{\circ} \mathrm{C}$. The DTG (derivative thermogravimetry) curve revealed four main stages of weight loss. In the first stage, corresponding to peaks of 75 and $120^{\circ} \mathrm{C}$, loss of water physically adsorbed in the material is observed. In the second stage, corresponding to a peak of $208^{\circ} \mathrm{C}$, crystallization water loss of the solid structure was observed, thus forming an anhydrous acid (Equation (3)). In the third stage, corresponding to a peak of $305^{\circ} \mathrm{C}$, acidic proton loss and anhydride structure formation was observed (Equation (4)). Finally, in the fourth stage, corresponding to a peak of $545^{\circ} \mathrm{C}$, the Keggin structure starts 
decomposing (Equation (5)). According to Kozhevnikov et al. [28] and Alsalme et al. [29], this stage occurs at approximately $600^{\circ} \mathrm{C}$. Therefore, it can be concluded that the HPW Keggin structure remains after calcination at $300{ }^{\circ} \mathrm{C}$. However, the Keggin structure of the HPW catalyst calcined at $500{ }^{\circ} \mathrm{C}$ is close to its decomposition temperature, which explains the low yield observed for this catalyst.

$$
\begin{gathered}
\mathrm{H}_{3}\left[\mathrm{PW}_{12} \mathrm{O}_{40}\right] \cdot \mathrm{nH}_{2} \mathrm{O} \rightarrow \mathrm{H}_{3}\left[\mathrm{PW}_{12} \mathrm{O}_{40}\right]+\mathrm{nH}_{2} \mathrm{O}, \\
\mathrm{H}_{3}\left[\mathrm{PW}_{12} \mathrm{O}_{40}\right] \rightarrow\left[\mathrm{PW}_{12} \mathrm{O}_{38.5}\right]+1.5 \mathrm{H}_{2} \mathrm{O}, \\
{\left[\mathrm{PW}_{12} \mathrm{O}_{38.5}\right] \rightarrow 0.5 \mathrm{P}_{2} \mathrm{O}_{5}+12 \mathrm{WO}_{3} .}
\end{gathered}
$$

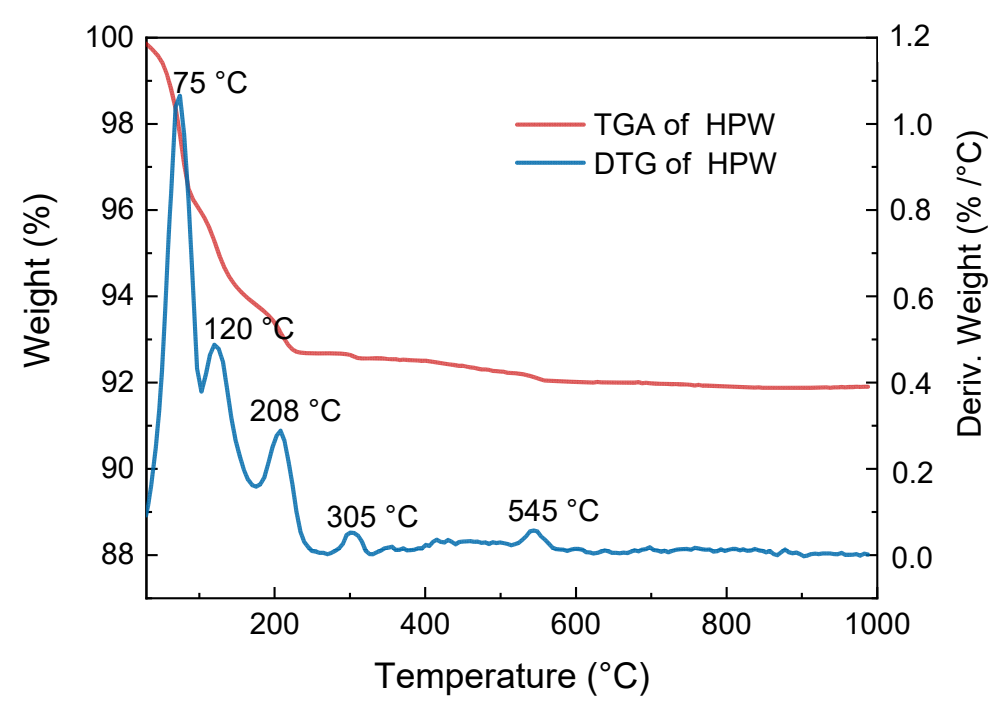

Figure 2. Thermogravimetric analysis (TGA) and derivative thermogravimetry (DTG) analysis of HPW samples.

The crystalline structures of the support $\left(\mathrm{Nb}_{2} \mathrm{O}_{5}\right)$, active phase (HPW), and catalyst $\left(\mathrm{HPW} / \mathrm{Nb}_{2} \mathrm{O}_{5}\right)$ calcined at $300{ }^{\circ} \mathrm{C}$ were evaluated by X-ray powder diffraction (XRD) (Figure 3). The XRD pattern of the HPW active phase showed typical diffraction peaks of a HPW Keggin structure at $10.3^{\circ}, 20.7^{\circ}, 23.1^{\circ}$, $25.4^{\circ}$, and $29.5^{\circ}[30,31]$. Such result indicates that the Keggin structure has not been decomposed into $\mathrm{WO}_{3}$ after calcination at $300{ }^{\circ} \mathrm{C}$, which could occur for the active phase calcined at $500{ }^{\circ} \mathrm{C}$. This result is in agreement with the thermogravimetry analysis results. The XRD pattern of the support $\left(\mathrm{Nb}_{2} \mathrm{O}_{5}\right)$ revealed an amorphous structure, with broad and diffuse diffraction peaks, which is characteristic of $\mathrm{Nb}_{2} \mathrm{O}_{5}$ calcined below $500{ }^{\circ} \mathrm{C}[32,33]$. Finally, the XRD pattern of the HPW/ $\mathrm{Nb}_{2} \mathrm{O}_{5}-300{ }^{\circ} \mathrm{C}$ catalyst was similar to that of the support with an amorphous characteristic, and exhibited no diffraction peak connected with HPW. This result indicates that HPW was well dispersed on the support surface, with no active phase agglomerations.

The HPW/ $\mathrm{Nb}_{2} \mathrm{O}_{5} / 300{ }^{\circ} \mathrm{C}$ catalyst morphology and structure, and HPW dispersion over the niobium pentoxide surface was investigated by scanning electron microscopy coupled with energy dispersive X-ray spectroscopy (SEM/EDX). As it can be seen in Figure 4, it is composed of non-uniform crystals with an irregular surface and particles of various sizes. It was not possible to identify a predominant crystalline structure in this catalyst, which was expected, since $\mathrm{Nb}_{2} \mathrm{O}_{5}$ calcined at $300^{\circ} \mathrm{C}$ exhibited an amorphous characteristic. According to the X-ray emission mapping of niobium and tungsten (Figure 4c,d), it is noted that the heteropolyacid was highly dispersed on the support surface, with no active phase agglomeration, which is in agreement with the XRD pattern obtained for the catalyst. 


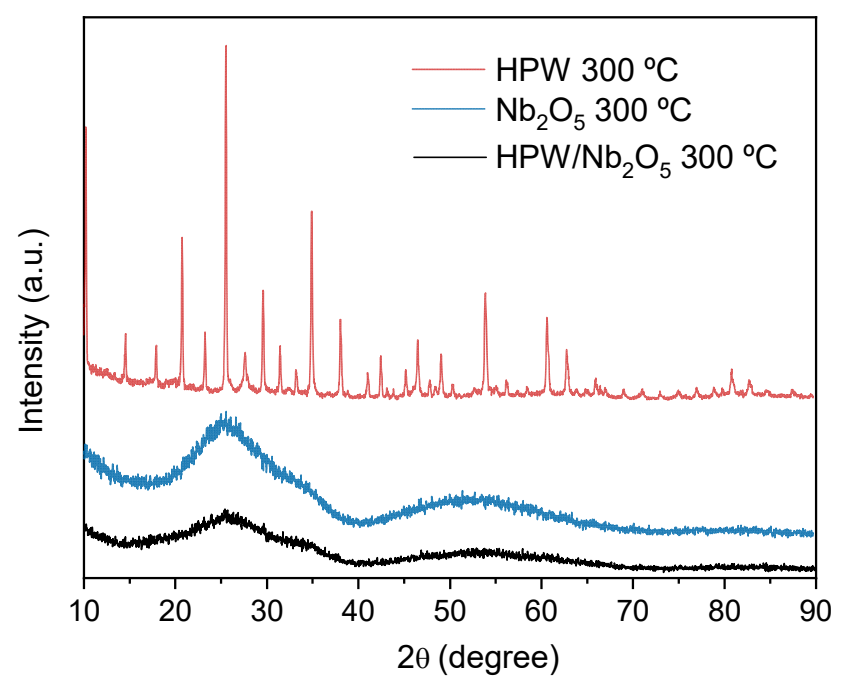

Figure 3. X-ray powder diffraction (XRD) patterns of the HPW active phase, $\mathrm{Nb}_{2} \mathrm{O}_{5}$ support, and $\mathrm{HPW} / \mathrm{Nb}_{2} \mathrm{O}_{5}$ catalyst calcined at $300{ }^{\circ} \mathrm{C}$.

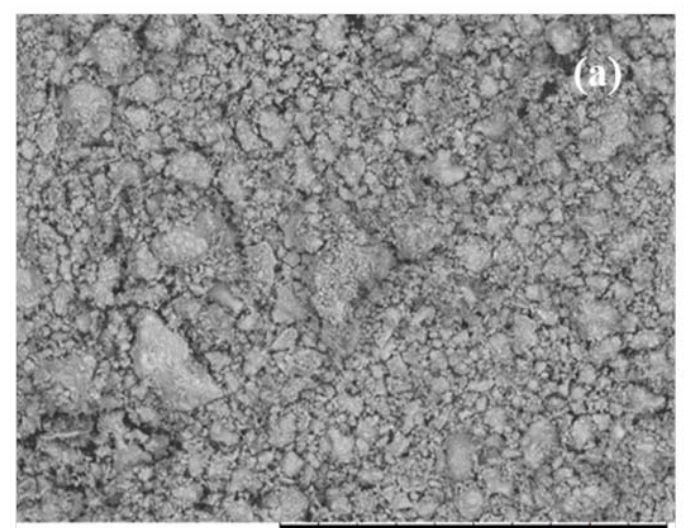

$500 \mu \mathrm{m}$

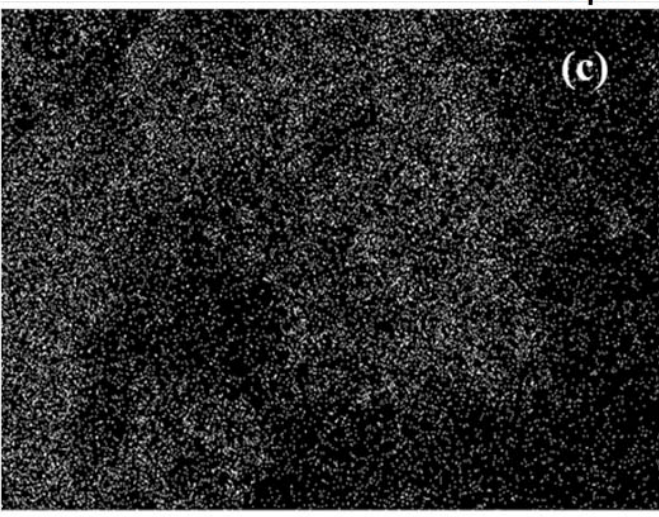

$40 \mu \mathrm{m}$

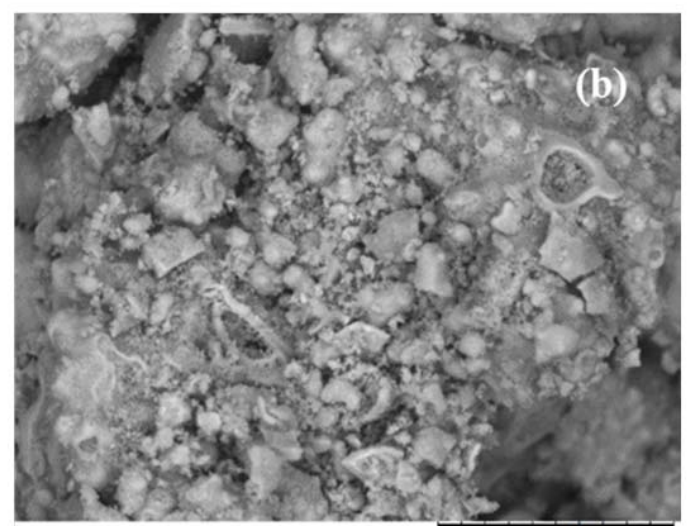

$30 \mu \mathrm{m}$

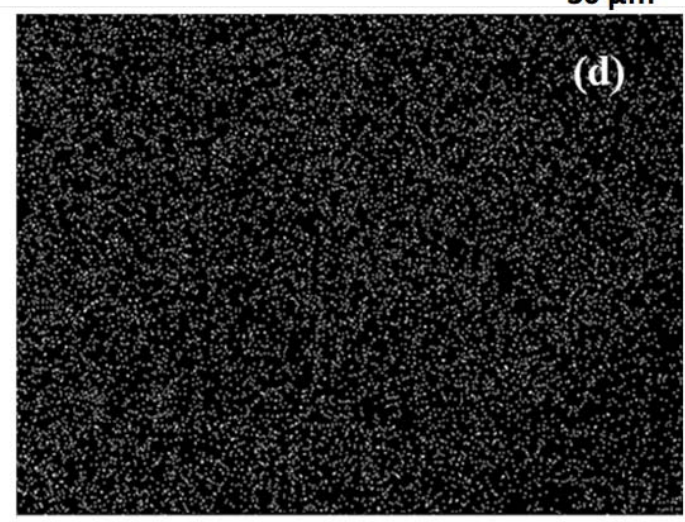

$40 \mu \mathrm{m}$

Figure 4. Scanning electron micrographs of $\mathrm{HPW} / \mathrm{Nb}_{2} \mathrm{O}_{5}-300{ }^{\circ} \mathrm{C}$ catalyst at (a) $200 \times$ magnification (scale bar: $500 \mu \mathrm{m}$ ), (b) $2000 \times$ magnification (scale bar: $30 \mu \mathrm{m}$ ), and X-ray emission mapping of niobium (c) and tungsten (d) obtained at 2000× magnification (scale bar: $40 \mu \mathrm{m}$ ).

Textural and acidity properties of the niobium support and selected catalyst $\left(\mathrm{HPW} / \mathrm{Nb}_{2} \mathrm{O}_{5}-300{ }^{\circ} \mathrm{C}\right)$ were also analyzed. As depicted in Table 3, the support showed values of surface area and volume of pores greater than those obtained for the catalyst $\mathrm{HPW} / \mathrm{Nb}_{2} \mathrm{O}_{5} / 300^{\circ} \mathrm{C}$, since $\mathrm{HPW}$ impregnation onto the support leads to a massive reduction in these parameters. This occurs because the HPW Keggin 
structure is dispersed within the support pores $\left(\mathrm{Nb}_{2} \mathrm{O}_{5}\right)$, causing a decrease in average pore volume and surface area. Decreased surface area of the catalyst $\mathrm{HPW} / \mathrm{Nb}_{2} \mathrm{O}_{5} / 300{ }^{\circ} \mathrm{C}$ can be understood as an evidence of the chemical interaction between HPW and the support. Surface acidity is an important property which affects catalyst performance in the reaction and may be indicative of an impregnation success. HPW/ $/ \mathrm{Nb}_{2} \mathrm{O}_{5} / 300{ }^{\circ} \mathrm{C}$ showed acidity of $106.98 \mu \mathrm{mol} \mathrm{H} \mathrm{H}^{+} / \mathrm{m}^{2}$, i.e., much higher than that of $\mathrm{Nb}_{2} \mathrm{O}_{5}$ used as support.

Table 3. Textural and acidity properties of $\mathrm{Nb}_{2} \mathrm{O}_{5}$ and $\mathrm{HPW} / \mathrm{Nb}_{2} \mathrm{O}_{5}$ catalyst.

\begin{tabular}{cccc}
\hline Sample & Surface Area $\left(\mathbf{m}^{2} / \mathbf{g}\right)$ & Pore Volume $\left(\mathrm{cm}^{3} / \mathbf{g}\right)$ & $\begin{array}{c}\text { Surface Acidity } \\
\left(\mu \mathbf{m o l ~}^{+} / \mathbf{~ m}^{2}\right)\end{array}$ \\
\hline $\mathrm{Nb}_{2} \mathrm{O}_{5}$ & 130.91 & 0.14 & 0.31 \\
$\mathrm{HPW} / \mathrm{Nb}_{2} \mathrm{O}_{5}-300{ }^{\circ} \mathrm{C}$ & 36.08 & 0.031 & 106.98 \\
\hline
\end{tabular}

\subsection{Reaction Conditions Evaluation}

In this section, Taguchi's $\mathrm{L}_{16}$ experimental design was used for optimizing reaction conditions so as to produce $\mathrm{HMF}$ from glucose using the selected catalyst $\mathrm{HPW} / \mathrm{Nb}_{2} \mathrm{O}_{5} / 300{ }^{\circ} \mathrm{C}$. Different reaction conditions and responses are summarized in Table 4. As it can be seen, HMF yield obtained in these experiments ranged from $7.6 \%$ to $40.8 \%$. As in the previous stage, high glucose conversion was obtained, i.e., ranging from $63.7 \%$ to $98.4 \%$, which could also be associated with by-products formation. The highest HMF yield (40.8\%) was obtained under the conditions of assay $2\left(160{ }^{\circ} \mathrm{C}, 5 \% w / v\right.$ of catalyst, $50 \mathrm{~g} / \mathrm{L}$ of glucose, 1:1 v/v acetone-to-water, $300 \mathrm{rpm}$ and reaction time of $30 \mathrm{~min}$ ). 
Table 4. Taguchi's $\mathrm{L}_{16}$ orthogonal array to evaluate the effect of temperature, acetone-to-water ratio, glucose concentration, and catalyst concentration on 5-Hydroxymethylfurfural production from glucose.

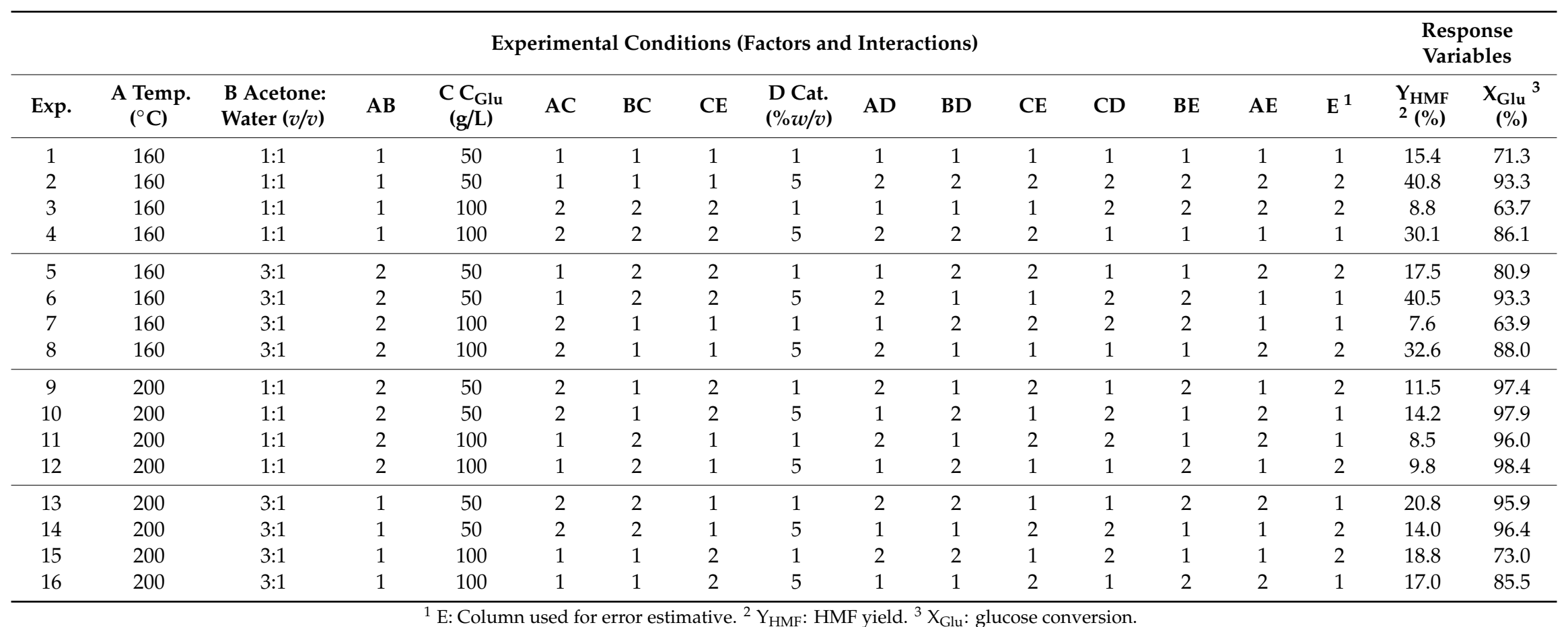

${ }^{1}$ E: Column used for error estimative. ${ }^{2} \mathrm{Y}_{\mathrm{HMF}}$ : HMF yield. ${ }^{3} \mathrm{X}_{\mathrm{Glu}}$ : glucose conversion. 
The statistical significance of the main effects and interactions on response variables was found by the analysis of variance (ANOVA) (Table 5). Percentages of variation in HMF yield and glucose conversion showed high correlation coefficients $\left(R^{2}\right)$, i.e., over $95 \%$ confidence level. The statistical analysis showed that, for HMF yield, reaction temperature (A), acetone-to-water ratio (B), glucose (C) and catalyst concentration (D), and AC and AD interactions were significant at $95 \%$ confidence level. Regarding glucose conversion, reaction temperature (A), glucose (C) and catalyst concentration (D), and $\mathrm{AB}$ and $\mathrm{AD}$ interactions were significant at the same confidence level.

Table 5. Analysis of variance of response variables evaluated in the experimental design Taguchi $\mathrm{L}_{16}$.

\begin{tabular}{ccc}
\hline \multirow{2}{*}{ Source of Variation } & \multicolumn{2}{c}{ Response Variables } \\
\cline { 2 - 3 } & $\boldsymbol{p}$-Value for $\mathbf{Y}_{\text {HMF }}$ & $\boldsymbol{p}$-Value for $\mathbf{X}_{\mathrm{Glu}}$ \\
\hline (A) $\mathrm{T}_{\text {reaction }}$ & $0.000^{*}$ & $0.002 *$ \\
(B) Acetone:Water & $0.027^{*}$ & 0.168 \\
(C) $\mathrm{C}_{\text {glucose }}$ & $0.007^{*}$ & $0.008^{*}$ \\
(D) $\mathrm{C}_{\text {catalyst }}$ & $0.000^{*}$ & $0.002^{*}$ \\
$\mathrm{AB}$ & 0.058 & $0.031^{*}$ \\
$\mathrm{AC}$ & $0.030^{*}$ & 0.889 \\
$\mathrm{AD}$ & $0.000^{*}$ & $0.012^{*}$ \\
$\mathrm{BC}$ & 0.448 & 0.063 \\
$\mathrm{BD}$ & 0.290 & 0.902 \\
$\mathrm{CD}$ & 0.874 & 0.185 \\
\hline $\mathrm{R}^{2}$ & 0.984 & 0.960 \\
\hline
\end{tabular}

* Significant at $95 \%$ confidence level: $p$ test $<0.05$.

Figure 5 shows the signal-to-noise ratio (SN ratio) diagrams of HMF yield (A) and glucose conversion (B). It is possible to determine optimal conditions for HMF production from glucose thereof. According to Figure 5A, the highest HMF yield was achieved when reaction temperature and glucose concentration were at the lowest level (temperature of $160{ }^{\circ} \mathrm{C}$ and $50 \mathrm{~g} / \mathrm{L}$ of glucose), while catalyst concentration was at the highest level $(5 \% w / v)$. Acetone-to-water ratio was insignificant for HMF yield in the range of values studied herein.

With respect to glucose conversion (Figure 5B), the highest conversion rates were achieved when reaction temperature, acetone-to-water ratio, and catalyst concentration were at the highest level $\left(200{ }^{\circ} \mathrm{C}, 3: 1 v / v, 5 \% w / v\right.$, respectively), while glucose concentration was insignificant within the studied range of values. It is interesting to note that glucose conversion was the only response variable that obtained a better result when at high reaction temperatures. This suggests that, for the studied range of values, high reaction temperatures may favor by-product formation.

According to results of the statistical analysis and considering that this paper aimed to obtain the highest HMF yield, optimal conditions for HMF production from glucose in the evaluated range of values was temperature of $160^{\circ} \mathrm{C}, 1: 1(v / v)$ acetone-to-water ratio, glucose concentration of $50 \mathrm{~g} / \mathrm{L}$, and catalyst concentration of $5 \% w / v$. 

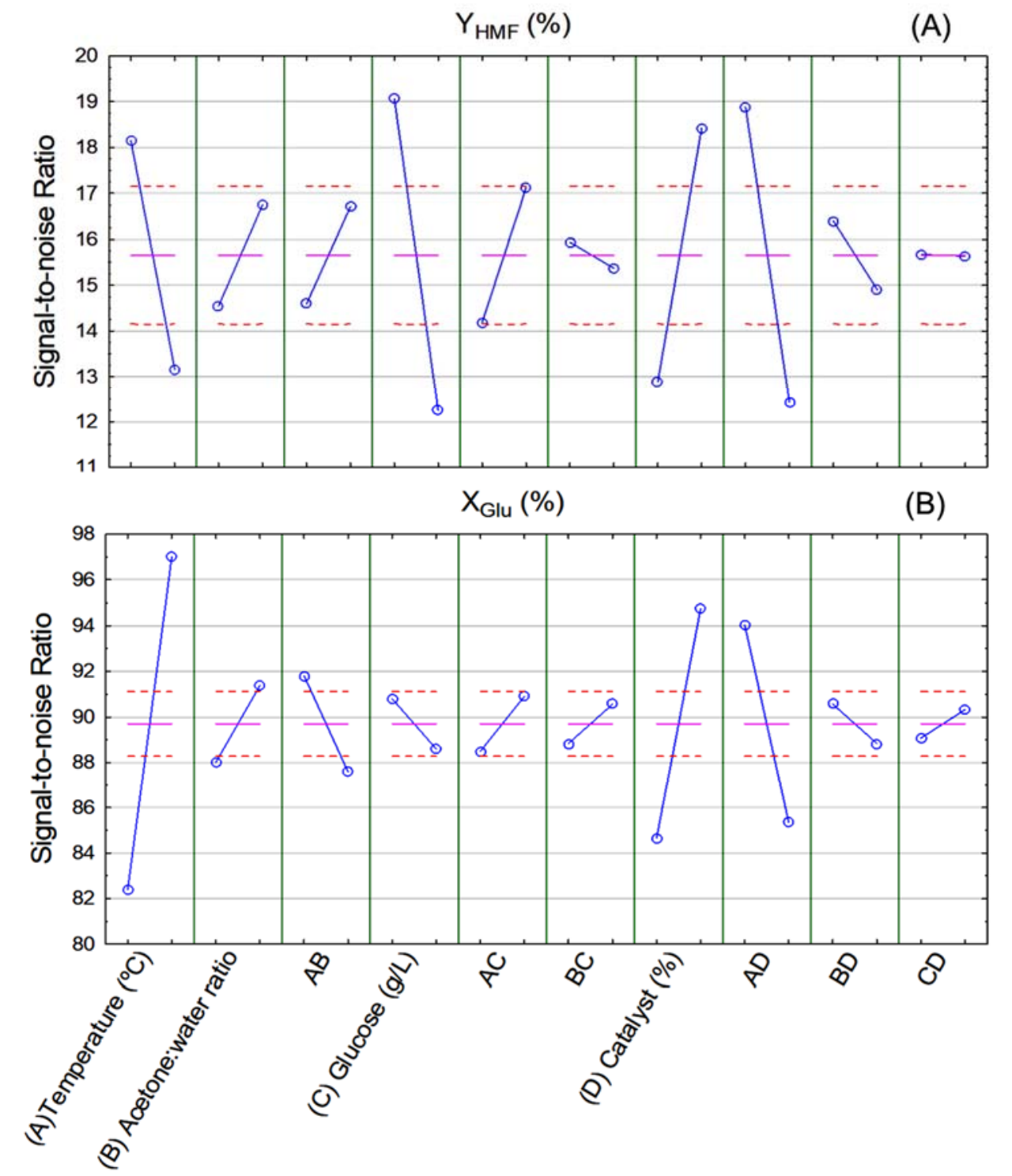

Figure 5. Signal-to-noise ratio (SN ratio) of (A) HMF yield ( $\left.\mathrm{Y}_{\mathrm{HMF}} \%\right)$ and (B) glucose conversion $\left(\mathrm{X}_{\mathrm{Glu}}\right.$ $\%)$ response variables.

The catalytic performance of $\mathrm{HPW} / \mathrm{Nb}_{2} \mathrm{O}_{5}$ was compared with some recent reported studies in literature that produce HMF from glucose, as shown in Table 6. The HMF yield (40.8\%) obtained in the present study using $\mathrm{HPW} / \mathrm{Nb}_{2} \mathrm{O}_{5}$ as catalyst and water/acetone was higher than most studies reported in the literature which used heterogeneous catalyst [34-36], even when organic phase [37] or ionic liquid [11] was applied as solvent. Teimouri et al. [38], who used the same solvent as the present work (water/acetone), achieved lower HMF yield (34.6\%), even using higher reaction temperature and time. Huang et al. [26], who used the same reaction temperature and time but different solvent (Water/ $\gamma$-valerolactone), also obtained lower HMF yield compared to the present work. Shahangi et al. [9], Shen et al. [39], Zhang et al. [10], and Moreno-Recio et al. [40] achieved similar HMF yield obtained in this work, however all of them applied more drastic reaction conditions, as higher temperature and/or time. In general, even using acetone/water as a reaction medium, we achieved HMF yield equivalent to the highest values reported in the literature, but with milder reaction conditions. 
Table 6. Comparison of the performance of $\mathrm{HPW} / \mathrm{Nb}_{2} \mathrm{O}_{5}-300^{\circ} \mathrm{C}$ catalyst with some recent works reported in literature on $\mathrm{HMF}$ production from glucose.

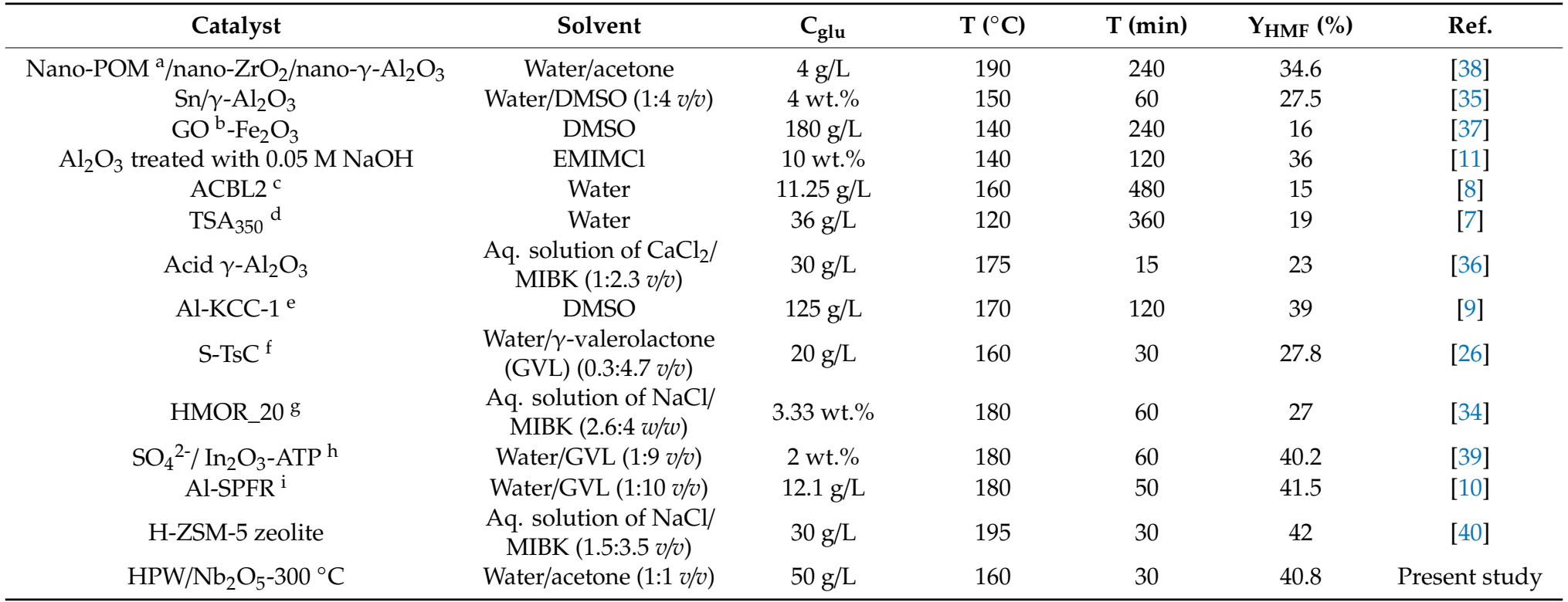

a POM; Polyoxometalates. ${ }^{\mathrm{b}} \mathrm{GO}$; Graphene oxide. ${ }^{\mathrm{c}}$ ACBL2; Activated carbon with acid treatment $18 \mathrm{M} \mathrm{H}_{2} \mathrm{SO}_{4}$ and activated carbon with 15 wt. $\%$ of zinc. ${ }^{\mathrm{d}}$ TSA 350 ; Alumina-promoted sulfated tin oxide calcined at $350{ }^{\circ} \mathrm{C} .{ }^{\mathrm{e}} \mathrm{Al}-\mathrm{KCC}-1$; Aluminosilicate with $\mathrm{Si} / \mathrm{Al}=5 .{ }^{\mathrm{f}} \mathrm{S}-\mathrm{TsC}$; Sulfonated tobacco stem-derived porous carbon. ${ }^{\mathrm{g}} \mathrm{HMOR} \_20$; zeolite with $\mathrm{SiO} / 2 / \mathrm{AlO}_{3}=20 .{ }^{\mathrm{h}} \mathrm{ATP}$; Attapulgite. ${ }^{\mathrm{i}} \mathrm{Al}$-SPFR; $\mathrm{Al}^{3+}$-modified formaldehyde-p-hydroxybenzenesulfonic acid resin catalyst. 


\subsection{Catalyst Recycling Test}

Finally, the $\mathrm{HPW} / \mathrm{Nb}_{2} \mathrm{O}_{5}-300{ }^{\circ} \mathrm{C}$ catalyst stability was evaluated through a recycling test using optimal reaction conditions for HMF production from glucose. Figure 6 shows that the catalyst was capable of maintaining the HMF yield constant at approximately $40 \%$ during four runs. This means that a simple calcination process was sufficient to eliminate by-products (humin) that could have covered some active sites of the catalyst. This result indicates that the catalyst $\mathrm{HPW} / \mathrm{Nb}_{2} \mathrm{O}_{5}-300{ }^{\circ} \mathrm{C}$ has high stability, good recyclability, and low active phase leaching, thus confirming its effectiveness to be used in HMF production from glucose.

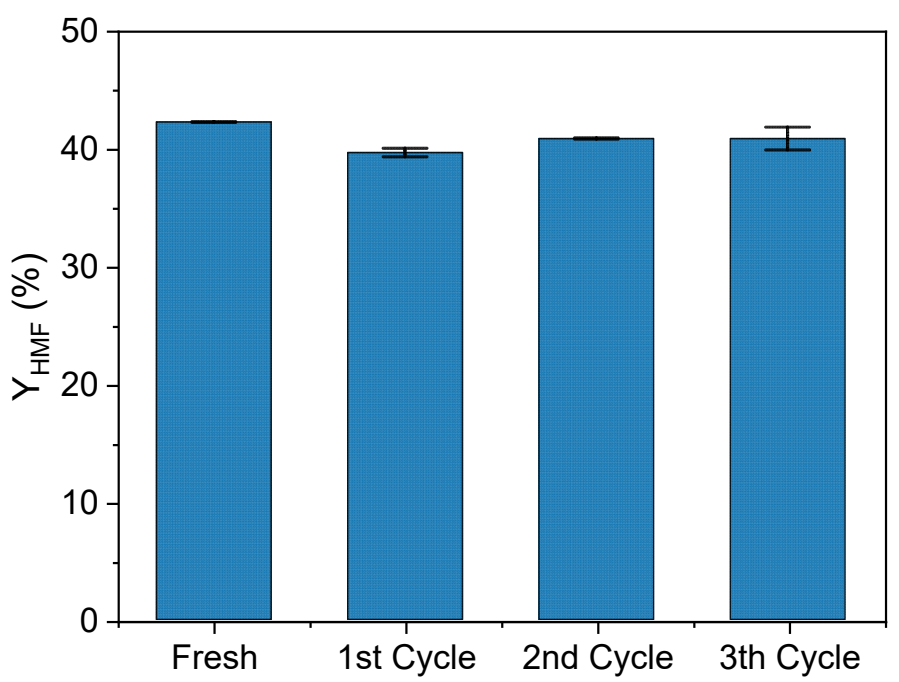

Figure 6. Catalytic performance of $\mathrm{HPW} / \mathrm{Nb}_{2} \mathrm{O}_{5}-300{ }^{\circ} \mathrm{C}$ during a recycling test. Reaction conditions were $160{ }^{\circ} \mathrm{C}, 5 \% \mathrm{w} / \mathrm{v}$ of catalyst, $50 \mathrm{~g} / \mathrm{L}$ of glucose, $1: 1 \mathrm{v} / \mathrm{v}$ acetone-to-water, $300 \mathrm{rpm}$, and reaction time of $30 \mathrm{~min}$.

\section{Conclusions}

This study revealed that the conditions used for preparing the heterogeneous catalysts based on heteropolyacids, i.e., type of support, active phase, and calcination temperature, strongly affects catalyst performance to convert glucose into HMF. The heterogeneous catalyst prepared by using $\mathrm{HPW}$ as active phase, supported in $\mathrm{Nb}_{2} \mathrm{O}_{5}$, and calcined at $300{ }^{\circ} \mathrm{C}$ presented optimal performance at obtaining HMF yield (9.5\%) with 1:1 w/w acetone-to-water ratio, $160{ }^{\circ} \mathrm{C}, 1 \% w / v$ of catalyst, $100 \mathrm{~g} / \mathrm{L}$ of glucose and reaction time of $30 \mathrm{~min}$. After optimizing reaction conditions (temperature at $160{ }^{\circ} \mathrm{C}$, 1:1 (v/v) acetone-to-water ratio, glucose concentration of $50 \mathrm{~g} / \mathrm{L}$, and catalyst concentration of $5 \% \mathrm{w} / \mathrm{v})$, HMF yield increased to $40.8 \%$. The catalyst presented high stability and is capable of maintaining HMF yield at around $40 \%$, even after four runs. This was the first time that a catalyst based on HPW and $\mathrm{Nb}_{2} \mathrm{O}_{5}$ was used for HMF production from glucose. The promising results here obtained will open up new opportunities to expand HMF production from lignocellulosic biomass. The possibility of recycling the catalyst is also a point to be highlighted contributing to the sustainability aspect of the proposed process.

Author Contributions: Conceptualization, J.P.A.S., S.I.M. and L.M.C.; Methodology, J.S.M.N., J.P.A.S. and L.M.C.; Software, J.S.M.N., J.P.A.S. and L.M.C.; Investigation, J.S.M.N., J.P.A.S and L.M.C.; Resources, J.P.A.S, S.I.M. and L.M.C.; Writing-Original Draft, J.S.M.N. and L.M.C.; Writing-Review and Editing, J.P.A.S, S.I.M. and L.M.C.; Supervision, J.P.A.S, S.I.M. and L.M.C.; Project Administration, J.P.A.S, S.I.M. and L.M.C.; Funding Acquisition, J.P.A.S, S.I.M. and L.M.C. All authors have read and agreed to the published version of the manuscript.

Funding: This research was funded by Fundação de Amparo à Pesquisa do Estado de São Paulo (FAPESP), project number 2017/24050-8 and 2018/03714-8, Brazil; Conselho Nacional de Desenvolvimento Científico e Tecnológico (CNPq), Brazil; Coordenação de Aperfeiçoamento de Pessoal de Nível Superior (CAPES), Brazil; and Novo Nordisk Foundation, grant number: NNF10CC1016517, Denmark. 
Acknowledgments: We thank Companhia Brasileira de Metalurgia e Mineração (CBMM) for donations the materials used for experiments.

Conflicts of Interest: The authors declare no conflict of interest.

\section{References}

1. Mussatto, S.I. (Ed.) Biomass Fractionation Technologies for a Lignocellulosic Feedstock Based Biorefinery; Elsevier Inc.: Waltham, MA, USA, 2016; p. 674. ISBN 9780128023235.

2. Werpy, T.; Petersen, G.; National Renewable Energy Laboratory (NREL). Top Value Added Chemicals from Biomass. Volume I-Results of Screening for Potential Candidates from Sugars and Synthesis Gas. 2004. Available online: https://www.nrel.gov/docs/fy04osti/35523.pdf (accessed on 3 September 2019).

3. Mukherjee, A.; Dumont, M.J.; Raghavan, V. Review: Sustainable production of hydroxymethylfurfural and levulinic acid: Challenges and opportunities. Biomass Bioenergy 2015, 72, 143-183. [CrossRef]

4. Jong, E.; Dam, M.A.; Sipos, L.; Gruter, J.M. Furandicarboxylic acid (FDCA), a versatile building block for a very interesting class of polyesters. In Biobased Monomers, Polymers, and Materials; Smith, P.B., Gross, R.A., Eds.; American Chemical Society: Midland, MI, USA, 2012; Volume 1105, pp. 1-13. [CrossRef]

5. Sweygers, N.; Alewaters, N.; Dewil, R.; Appels, L. Microwave effects in the dilute acid hydrolysis of cellulose to 5-hydroxymethylfurfural. Sci. Rep. 2018, 8, 1-11. [CrossRef] [PubMed]

6. Candu, N.; Fergani, M.E.; Verziu, M.; Cojocaru, B.; Jurca, B.; Apostol, N.; Teodorescu, C.; Parvulescu, V.I.; Coman, S.M. Efficient glucose dehydration to HMF onto Nb-BEA catalysts. Catal. Today 2019, 325, $109-116$. [CrossRef]

7. Lopes, M.; Dussan, K.; Leahy, J.J.; Da Silva, V.T. Conversion of d-glucose to 5-hydroxymethylfurfural using $\mathrm{Al}_{2} \mathrm{O}_{3}$-promoted sulphated tin oxide as catalyst. Catal. Today 2017, 279, 233-243. [CrossRef]

8. Rusanen, A.; Lahti, R.; Lappalainen, K.; Kärkkäinen, J.; Hu, T.; Romar, H.; Lassi, U. Catalytic conversion of glucose to 5-hydroxymethylfurfural over biomass based activated carbon catalyst. Catal. Today 2019. [CrossRef]

9. Shahangi, F.; Chermahini, A.N.; Saraji, M. Dehydration of fructose and glucose to 5-hydroxymethylfurfural over Al-KCC-1 silica. J. Energy Chem. 2018, 27, 769-780. [CrossRef]

10. Zhang, T.; Li, W.; Xin, H.; Jin, L.; Liu, Q. Production of HMF from glucose using an $\mathrm{Al}^{3+}$-promoted acidic phenol-formaldehyde resin catalyst. Catal. Commun. 2019, 124, 56-61. [CrossRef]

11. Hou, Q.; Zhen, M.; Li, W.; Liu, L.; Liu, J.; Zhang, S.; Nie, Y.; Bai, C.; Bai, X.; Ju, M. Efficient catalytic conversion of glucose into 5-hydroxymethylfurfural by aluminum oxide in ionic liquid. Appl. Catal. B Environ. 2019, 253, 1-10. [CrossRef]

12. Daorattanachai, P.; Khemthong, P.; Viriya-empikul, N.; Laosiripojana, N.; Faungnawakij, K. Effect of calcination temperature on catalytic performance of alkaline earth phosphates in hydrolysis/dehydration of glucose and cellulose. Chem. Eng. 2015, 278, 92-98. [CrossRef]

13. Gomes, F.N.D.C.; Pereira, L.R.; Riberiro, N.F.P.; Souza, M.M.V.M. Production of 5-hydroxymethylfurfural (HMF) via fructose dehydration: Effect of solvent and salting-out. Braz. J. Chem. Eng. 2015, 32, 119-126. [CrossRef]

14. Yuan, B.; Guan, J.; Peng, J.; Guang-Zhou, Z.; Ji-Hong, J. Green hydrolysis of corncob cellulose into 5-hydroxymethylfurfural using hydrophobic imidazole ionic liquids with a recyclable, magnetic metalloporphyrin catalyst. Chem. Eng. J. 2017, 330, 109-119. [CrossRef]

15. Yan, D.; Xin, J.; Shi, C.; Lu, X.; Ni, L.; Wang, G.; Zhang, S. Base-free conversion of 5-hydroxymethylfurfural to 2,5-furandicarboxylic acid in ionic liquids. Chem. Eng. J. 2017, 323, 473-482. [CrossRef]

16. Boisen, A.; Christensen, T.B.; Fu, W.; Gorbanev, Y.Y.; Hansen, T.S.; Jensen, J.S.; Klitgaad, S.K.; Pedersen, S.; Riisager, A.; Stahlberg, T.; et al. Process integration for the conversion of glucose to 2,5-furandicarboxilic acid. Chem. Eng. Res. Des. 2009, 87, 1318-1327. [CrossRef]

17. Kale, S.S.; Armbruster, U.; Eckelt, R.; Bentrup, U.; Umbarkar, S.B.; Dongare, M.K.; Martin, A. Understanding the role of Keggin type heteropolyacid catalysts for glycerol acetylation using toluene as an entrainer. Appl. Catal. A Gen. 2016, 527, 9-18. [CrossRef]

18. Mansir, N.; Taufiq-Yap, Y.H.; Rashid, U.; Lokman, I.M. Investigation of heterogeneous solid catalyst performance on low grade feedstocks for biodiesel production: A review. Energy Convers. Manag. 2017, 141, 171-182. [CrossRef] 
19. Méndez, F.J.; Llanos, A.; Echeverría, M.; Jáuregui, R.; Villasana, Y.; Díaz, Y.; Liendo-Polanco, G.; Ramos-García, M.A.; Zoltan, T.; Brito, J.L. Mesoporous catalysts based on Keggin-type heteropolyacids supported on MCM-41 and their application in thiphene hydrodesulfurization. Fuel 2013, 110, $249-258$. [CrossRef]

20. Marcí, G.; García-Lopez, E.; Vaiano, V.; Sarno, G.; Sannino, D.; Palmisano, L. Keggin heteropolyacid supported on $\mathrm{TiO}_{2}$ used in gas-solid (photo)catalytic propene hydration and in liquid-solid photocatalytic glycerol dehydration. Catal. Today 2017, 281, 60-70. [CrossRef]

21. Han, X.; Yan, W.; Chen, K.; Hung, C.T.; Liu, L.L.; Wu, P.H.; Huang, S.J.; Liu, S.B. Heteropolyacid-based ionic liquids as effective catalysts for the synthesis of benzaldehyde glycol acetal. Appl. Catal. A Gen. 2014, 485, 149-156. [CrossRef]

22. Pinto, T.; Dufaud, V.; Lefebvre, F. Isomerization of $\mathrm{n}$-hexane on heteropolyacids supported on SBA-15. 1. Monofunctional impregnated catalysts. Appl. Catal. A Gen. 2014, 483, 103-109. [CrossRef]

23. Hu, L.; Sun, Y.; Lin, L.; Liu, S. 12-Tungstophosphoric acid/boric acid as synergetic catalysts for the conversion of glucose into 5-hydroxymethylfurfural in ionic liquid. Biomass Bioenergy 2012, 47, 289-294. [CrossRef]

24. Zhao, P.; Zhang, Y.; Wang, Y.; Cui, H.; Song, F.; Sun, X.; Zhang, L. Conversion of glucose into 5-hydroxymethylfurfural catalyzed by acid-base bifunctional heteropolyacid-based ionic hybrids. Green Chem. 2018, 20, 1551-1559. [CrossRef]

25. Fan, C.; Guan, H.; Zhang, H.; Wang, J.; Wang, S.; Wang, X. Conversion of fructose and glucose into 5-hydroxymethylfurfural catalyzed by a solid heteropolyacid salt. Biomass Bioenergy 2011, 35, 2659-2665. [CrossRef]

26. Huang, F.; Su, Y.; Tao, Y.; Sun, W.; Wang, W. Preparation of 5-hydroxymethylfurfural from glucose catalyzed by silicasupported phosphotungstic acid heterogeneous catalyst. Fuel 2018, 226, 417-422. [CrossRef]

27. Martín, C.; Solana, G.; Malet, P.; Rives, V. $\mathrm{Nb}_{2} \mathrm{O}_{5}$-supported $\mathrm{WO}_{3}$ : A comparative study with $\mathrm{WO}_{3} / \mathrm{Al}_{2} \mathrm{O}_{3}$. Catal. Today 2003, 78, 365-376. [CrossRef]

28. Kozhevnikov, I.V. Sustainable heterogeneous acid catalysis by heteropoly acids. J. Mol. Catal. A Chem. 2007, 262, 86-92. [CrossRef]

29. Alsalme, A.M.; Wiper, P.V.; Khimyak, Y.Z.; Kozhevnikova, E.F.; Kozhevnikov, I.V. Solid acid catalysts based on $\mathrm{H}_{3} \mathrm{PW}_{12} \mathrm{O}_{40}$ heteropoly acid: Acid and catalytic properties at a gas-solid interface. J. Catal. 2010, 276, 181-189. [CrossRef]

30. Keggin, J.F. Structure and formula of 12-phosphotungstic acid. Proc. R. Soc. Lond. Ser. A Math. Phys. Eng. Sci. 1934, 144, 75-100. [CrossRef]

31. Liao, X.; Huang, Y.; Zhou, Y.; Liu, H.; Cai, Y.; Lu, S.; Yao, Y. Homogeneously dispersed HPW/graphene for high efficient catalytic oxidative desulfurization prepared by electrochemical deposition. Appl. Surf. Sci. 2019, 484, 917-924. [CrossRef]

32. Caliman, E.; Dias, J.A.; Dias, S.C.L.; Garcia, F.A.C.; Macedo, J.L.D.; Almeida, L.S. Preparation and characterization of $\mathrm{H}_{3} \mathrm{PW}_{12} \mathrm{O}_{40}$ supported on niobia. Microporous Mesoporous Mater. 2010, 132, $103-111$. [CrossRef]

33. Conceição, L.R.V.D.; Carneiro, L.M.; Giordani, D.S.; Castro, H.F.D. Synthesis of biodiesel from macaw palm oil using mesoporous solid catalyst comprising 12-molybdophosphoric acid and niobia. Renew. Energy 2017, 113, 119-128. [CrossRef]

34. Peela, N.R.; Yedla, S.K.; Velaga, B.; Kumar, A.; Golder, A.K. Choline chloride functionalized zeolites for the conversion of biomass derivatives to 5-hydroxymethykfurfural. Appl. Catal. A Gen. 2019, 580, 59-70. [CrossRef]

35. Marianou, A.A.; Michailof, C.M.; Pineda, A.; Iliopoulou, E.F.; Triantafyllidis, K.S.; Lappas, A.A. Effect of Lewis and Brønsted acidity on glucose conversion to 5-HMF and lactic acid in aqueous and organic media. Appl. Catal. A Gen. 2018, 555, 75-87. [CrossRef]

36. García-Sancho, C.; Fúnez-Núñez, I.; Moreno-Tost, T.; Santamaría-González, J.; Pérez-Inestrosa, E.; Fierro, J.L.G.; Maireles-Torres, P. Beneficial effects of calcium chloride on glucose dehydration to5-hydroxymethylfurfural in the presence of alumina as catalyst. Appl. Catal. B Environ. 2017, 206, 617-625. [CrossRef]

37. Zhang, Y.; Zhang, J.; Su, D. 5-Hydroxymethylfurfural: A key intermediate for efficient biomass conversion. J. Energy Chem. 2015, 24, 548-551. [CrossRef] 
38. Teimouri, A.; Mazaheri, M.; Chermahini, A.N.; Salavati, H.; Momenbeik, F.; Fazel-Najafabadi, M. Catalytic conversion of glucose to 5-hydroxymethylfurfural (HMF) using nano-POM/nano- $\mathrm{ZrO} 2 /$ nano- $\gamma-\mathrm{Al}_{2} \mathrm{O}_{3}$. J. Taiwan Inst. Chem. Eng. 2015, 49, 40-50. [CrossRef]

39. Shen, Y.; Kang, Y.; Sun, J.; Wang, C.; Wang, B.; Xu, F.; Sun, R. Efficient production of 5-hydroxymethylfurfural from hexoses using solid acid $\mathrm{SO}_{4}{ }^{-2} / \mathrm{In}_{2} \mathrm{O}_{3}$-ATP in a biphasic system. Chin. J. Catal. 2016, 37, 1362-1368. [CrossRef]

40. Moreno-Recio, M.; Santamaría-González, J.; Maireles-Torres, P. Brönsted and Lewis acid ZSM-5 zeolites for the catalytic dehydration of glucose into 5-hydroxymethylfurfural. Chem. Eng. J. 2016, 303, 22-30. [CrossRef]

(C) 2020 by the authors. Licensee MDPI, Basel, Switzerland. This article is an open access article distributed under the terms and conditions of the Creative Commons Attribution (CC BY) license (http://creativecommons.org/licenses/by/4.0/). 